\title{
Activity patterns of arboreal mammals in a tropical rain forest in México
}

\author{
Alberto Astiazarán Azcarraga ${ }^{1 *}$, Sonia Gallina Tessaro ${ }^{1}$, and Christian Alejandro Delfin-Alfonso ${ }^{2}$
}

\begin{abstract}
1 División de posgrado y Red de Biología y Conservación de Vertebrados, Instituto de Ecología A. C. Carretera Antigua a Coatepec 351, CP. 91073, El Haya. Xalapa, Veracruz, México. E-mail: albertoastiazaran1@gmail.com (AAA), sonia.gallina@inecol.mx (SAGT).

${ }^{2}$ Laboratorio de Zoología, Instituto de Investigaciones Biológicas, Universidad Veracruzana, Av. Luis Castelazo Ayala S/N, Col. Industrial Ánimas, CP. 91190, Xalapa. Veracruz, México. E-mail: cada7305@gmail.com (CAD-A).

* Corresponding author
\end{abstract}

\begin{abstract}
Studying activity patterns of canopy mammals provides information on the biology of these species. However, the challenges of reaching and sampling the forest canopy restrict the information available on activity patterns. This study aimed to describe the activity patterns of canopy mammals, and analyze their temporal overlap, in the Santa Gertrudis Ecological Reserve, State of Veracruz, Mexico. Camera trap records were obtained from February 2016 to February 2017. Nine camera traps were set in the study area, separated between 300 and 1500 $\mathrm{m}$ from each other, along a straight line in the forest canopy ( 8 to $12 \mathrm{~m}$ above the ground). Cameras were affixed to a trunk above a branch that was perpendicular to the line and overlapping a neighboring tree. A total of 12 mammal species that use the tree stratum were recorded, including two diurnal and ten nocturnal species. The five species for which at least ten records were obtained were included in the activity pattern analyses. Four of these are nocturnal species and showed temporal overlap values $\left(\Delta_{1}\right)$ ranging from 0.69 to 0.9 . Four of the 12 species recorded are listed in an extinctionrisk category as per the Norma Oficial Mexicana NOM. This is one of the first studies providing ecological information on activity patterns of canopy mammals in Mexico.
\end{abstract}

El estudio del patrón de actividad de los mamíferos del dosel ayuda a complementar la información básica sobre la biología de estas especies. Sin embargo, la dificultad por acceder al dosel para llevar a cabo el muestreo limita la información existente sobre sus patrones de actividad. El objetivo de la presente contribución fue describir el patrón de actividad y analizar el traslape temporal de los mamíferos de dosel en la Reserva Ecológica de Santa Gertrudis, Vega de Alatorre, Veracruz, México. Se obtuvieron los registros mediante cámaras-trampa durante un año de muestreo de febrero 2016 a febrero 2017. En el área se colocaron nueve trampas-cámara con una separación entre $300 \mathrm{~m}$ y 1.5 km en línea recta entre el dosel ( 8 a $12 \mathrm{~m}$ de altura), sujetadas al tronco por encima de una rama en posición perpendicular y con conexión con otro árbol. Se registró un total de 12 mamíferos que hacen uso del estrato arbóreo, de los cuales dos presentaron actividad diurna y 10 actividad nocturna. Únicamente de cinco obtuvimos 10 o más registros que nos permitieron llevar a cabo los análisis de patrones de actividad. Cuatro de estas especies fueron nocturnas y presentaron un coeficiente de traslape temporal de entre $\Delta_{1}=0.69$ a 0.9 . De las 12 especies registradas cuatro se encuentran catalogadas bajo alguna categoría de riesgo dentro de la legislación mexicana. Este estudio es uno de los primeros en aportar información ecológica con respecto a los patrones de actividad de un ensamble de mamíferos arborícolas en México.

Keywords: Canopy mammals; diurnal; ecological reserve; nocturnal; tropical forest.

(c) 2020 Asociación Mexicana de Mastozoología, www.mastozoologiamexicana.org

\section{Introduction}

The systematic study of daily habits of animals began in 1920 with the work of Szymanski (Halle and Stenseth 2000). Since then, several studies have been conducted on various animal species, mainly in captivity or laboratory conditions (DeCoursy 1990). Photographic cameras were first used by Pearson $(1959,1960)$ to monitor activity patterns of the California vole (Microtus californicus) in the late 1950s. Camera traps have allowed studying the temporal behavior of animals in natural and captivity conditions (e. g., Kachamakova and Zlatanova 2014). The development of more efficient camera traps has now allowed a better approach to the study of activity patterns (Oliveira-Santos et al. 2008). The use of camera traps provides a noninvasive research method that, with relatively little effort, yields information on multiple species, including those that are rare, elusive, or little known (Sanderson and Trolle 2005; Jimenez et al. 2010; O'Brien and Kinnaird 2011). In addition to their use for recording and documenting species presence, camera traps are also useful for recording their behavior, thus supporting the conduct of community-level analyses (Rowcliffe and Carbone 2008; Whitworth et al. 2016).

According to Halle and Stenseth (2000), studies on the temporal behavior of animals can be classified into two fields: 1) activity patterns, in which the activities of animals are examined during two periods of time: the active period, when animals perform activities such as foraging, defense of territory, exploration, and others; and the rest period, when animals carry out "comfort behavior", including sleeping, grooming, social contact, brood care, among others, and 2) time allocated to the various activities carried out by animals during the day.

Much of the knowledge on the activity patterns of mammals has come from studies on terrestrial species at ground level (e. g., Van Schaik and Griffiths 1996; Gómez et al. 2005; Gliwicz and Dabrowski 2007; Chen et al. 2009), whereas arboreal mammal species have been scarcely studied, mainly due to the technical challenges involved in observ- 
ing them in the forest canopy. However, the development of technology and affordable sampling techniques have made it possible to make progress in the study of the ecology of the forest canopy fauna (e. g., Charles-Dominique 1975; Van Schaik and Griffiths 1996; Schipper 2007; Bowler et al. 2017; Whitworth et al. 2016).

The description of activity patterns initially targeted a few rodent species including, for example, the red squirrel (Sciurus vulgaris) in coniferous forests and the Panamanian climbing rat (Tylomys panamensis) in tropical ecosystems (Wauters 2000; Mendez-Carvajal et al. 2015). FernándezDuque (2003) documented the activity pattern of the Azara's night monkey (Aotus azarae) in the western slope of South America, while Shipper (2007) monitored the kinkajou (Potos flavus) in Costa Rica. In recent years, similar studies have been carried out in tropical ecosystems around the world, particularly in Latin America, documenting the species richness of forest canopy mammals (Whitworth et al.2016). One of the earliest studies on forest canopy mammals that adopted a community-wide perspective was conducted in Brazil (Oliveira-Santos et al. 2008), in which the authors were able to document the presence of at least 11 mammal species in five families. The use of camera traps as a means to gather data on various species has become common in Mexico (Mandujano 2019). However, studies focusing on the community of forest canopy mammals in the Mexican tropics have not yet been carried out or published. For this reason, gathering ecological information on forest canopy mammals is now essential. This study aimed to document the species richness of mammals inhabiting the tree stratum, describing their activity patterns, and evaluating the temporal overlap between them in a tropical forest on the Gulf of Mexico.

\section{Materials and Methods}

The study was conducted in the Santa Gertrudis Ecological Reserve (RESG, for its acronym in Spanish), located in the Municipality of Vega de Alatorre, State of Veracruz, Mexico (19० $51^{\prime} 49.22^{\prime \prime}$ to $19^{\circ} 33^{\prime} 35.25^{\prime \prime} \mathrm{N}$ and $-96^{\circ} 32^{\prime} 27.49^{\prime \prime}$ to $-96^{\circ}$ $36^{\prime} 52.41^{\prime \prime} \mathrm{W}$; Figure 1). The RESG is a 1,000-ha private property dedicated to nature conservation and decreed as a federal Zone for Forest and Fauna Protection (SARH 1982). The dominant vegetation is a semideciduous tropical forest in different successional stages located at the northernmost limit of the distribution range of the humid tropical forest in Mexico. The study area also includes riparian forests

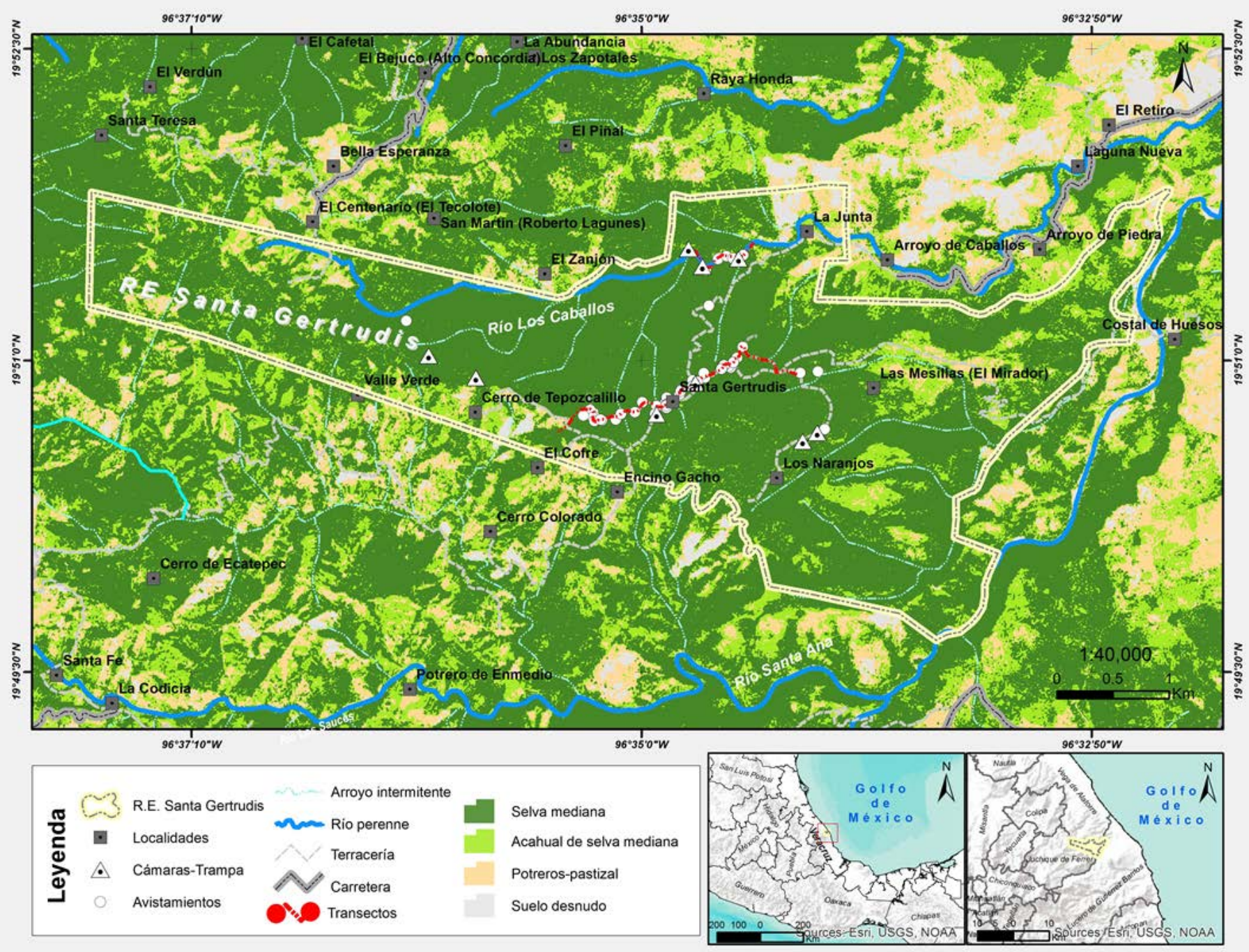

Figure 1. Map showing the location and boundaries of the Santa Gertrudis Ecological Reserve (RESG). 
(Godínez-lbarra and Lopez-Mata 2002), old coffee plantations, remnants of mountain cloud forests, and pastures (B. Vega Hernandez pers. comm). Elevation in the study area ranges between 80 and 940 masl and temperature, between 18.6 and $25.7^{\circ} \mathrm{C}$; the mean annual precipitation is $1,605 \mathrm{~mm}$ (CONAGUA 2016).

Data were collected employing camera traps over 12 months, from mid-February 2016 until mid-February 2017. Nine camera traps fitted with infrared motion sensors (Ltl. Acorn, Wild view Tk40, and Cuddeback (2) were installed. The camera traps were placed in the tree canopy ( 8 to $12 \mathrm{~m}$ above the ground), affixed to the trunk; these cameras were set focusing on a branch overlapping a neighboring tree. These interconnections between trees are known as "canopy highways" that allow mammals to move between trees and increase their probability of detection (Schipper 2007). We used tree climbing gear and techniques to reach the tree canopy. Camera traps were left operating during the entire sampling period and were checked monthly to retrieve the images captured and replace the batteries. The cameras were set to shoot three photographs per event at 1-min intervals.

All consecutive photographs of different species, as well as all photographs of the same species separated by at least one hour, were regarded as independent records. The distance between cameras ranged from 300 to 1,500 $\mathrm{m}$, depending on the terrain accessibility and availability of trees suitable for affixing the cameras. The trees selected had a diameter at breast height $(\mathrm{DBH}) \geq 40 \mathrm{~cm}$ and at least one branch overlapping those of other trees. The mammals recorded were identified based on specialized guides and literature (e. g., Emmons and Feer 1997; Reid 1997, 2004).

Activity patterns were elucidated using the software Oriana 4.0 (Kovach 2011). As recommended by Ridout and Linkie (2009), only those species with at least ten independent captures were included in these analyses. The times of capture were considered as a random sample taken at any time of the day. The activity pattern of each species was classified based on the hourly records. Data were grouped according to the classification proposed by Van Schaik and Griffiths (1996), as modified by Gómez et al. (2005). We identified four periods of activity: 1) diurnal, species with $\geq$ $70 \%$ of captures during the daytime, 2 ) nocturnal, species with $\geq 70 \%$ of captures during the night-time, 3 ) crepuscular, $50-60 \%$ of captures during twilight (the period one hour before and one hour after dawn or dusk), and 4) cathemeral, species with captures that showed no distinctive pattern or were randomly distributed along the daily cycle.

We used the package Overlap for R 3.4.1 (R Core Team 2014) to compare the activity patterns and evaluate the overlap between species. The coefficient of overlapping, $\Delta$, is defined as the area under the curve formed by taking the minimum of the two probability density functions at each time point (Ridout and Linkie 2009). The estimator $\Delta_{1}$ is recommended for analyzing activity patterns when the number of records is less than 25 (Ridout and Linkie 2009). Coefficient values range from 0 to 1 , with 0 indicating that the activities of species do not coincide at any time of the day, and $\sim 1$ or 1 that their times of activity are the same throughout the day (Ridout and Linkie 2009). We used the bootstrap method with 500 samples to construct $95 \%$ confidence intervals for $\Delta_{1}$ (Lynam et al. 2013).

\section{RESULTS}

We invested a total sampling effort of 2,664 camera-nights and collected 176 records of 12 species in seven families and four orders. All the species recorded showed a diurnal or nocturnal activity pattern; no species with crepuscular or cathemeral patterns were registered (Table 1).

Species Records and Abundance. The species most frequently recorded are common in tropical ecosystems (Table 1). However, we also recorded some species that are particularly important by their conservation status; these include the Mexican tree porcupine (Coendou mexicanus) and the margay (Leopardus wiedii), each with seven records, and the kinkajou (P. flavus) with 25records, the latter being one of the species most frequently recorded. It is worth noting that we documented two arboreal rodents: Peters's climbing rat (Tylomys nudicaudus), with 20 records, and the vesper rat (Nyctomys sumichrasti), with only one register. Our results show that the most abundant species was the Mexican gray squirrel (Sciurus aureogaster) with 53 records; the least abundant ones were two species in the family Didelphidae (Marmosa mexicana and Philander opossum) with one register each.

Daily Activity of Each Species. Only five of the 12 species recorded were included in the activity pattern analysis, due to the insufficient number $(<10)$ of independent records obtained for the remaining seven species (Table 1). Only one species, S. aureogaster, showed a diurnal pattern. The remaining four species were classified as nocturnal; their activity period comprised between 19:00 h and 5:00 h (Figure 2).

The activity of the four nocturnal species peaked between 22:00 $\mathrm{h}$ and 2:00 $\mathrm{h}$ and dropped towards dawn; they showed similar activity peaks. It should be noted that the activity period of the common opossum (Didelphis marsupialis) was more extended than those of the other species (Figure 2) and showed two activity peaks at both ends of the period: around 22:00 $\mathrm{h}$ and 4:00 $\mathrm{h}$.

Overlap of Activity Patterns Only the four nocturnal species were included in the analysis of the overlap of daily activity patterns. S. aureogaster was excluded because its activity pattern was entirely diurnal, with no overlap with the pattern of other species.

The activity patterns of the four species examined showed a relatively high level of overlap; the overlapping coefficients, $\Delta_{1}$, ranged from 0.696 to 0.919 (Figure 3). The estimated overall average overlapping of the combinations of the four species is close to 1 ( $\Delta_{1}=0.801 \pm 0.065 \mathrm{D}$. E.). D. marsupialis and T. nudicaudus were the species for which activity patterns showed the lowest overlap; the greatest overlap was found between T. mexicana and P. flavus (Figure 3). 
Table 1. Species recorded, common name, number of independent records, abundance index, period of activity, and activity pattern.

\begin{tabular}{|c|c|c|c|c|c|c|}
\hline Orden & Specie & Common name & $\begin{array}{l}\text { Number of } \\
\text { records }\end{array}$ & Abundance index & Time of activity & $\begin{array}{l}\text { Activity } \\
\text { pattern }\end{array}$ \\
\hline \multirow[t]{3}{*}{ Didelphimorphia } & Marmosa mexicana & Mouse opossum or Tlacuatzin & 1 & 0.375 & Nocturnal & $0: 15$ \\
\hline & Didelphis marsupialis & Opposum or Tlacuache & 41 & 15.390 & Nocturnal & $19: 00-5: 40$ \\
\hline & Philander opossum & $\begin{array}{l}\text { Four Eyes Opposum or Tlacuache de } \\
\text { cuatro ojos }\end{array}$ & 1 & 0.375 & Nocturnal & $22: 00$ \\
\hline Pilosa & Tamandua mexicana & Anteater or Oso hormiguero & 11 & 4.129 & Nocturnal & $21: 50-5: 02$ \\
\hline \multirow[t]{4}{*}{ Rodentia } & Nyctomys sumichrasti & Arboreal rodent or Ratón & 1 & 0.375 & Nocturnal & $00: 25$ \\
\hline & Tylomys nudicaudus & Arboreal Rat or Rata & 20 & 7.507 & Nocturnal & $20: 30-5: 10$ \\
\hline & Coendou mexicanus & Porcupine or Puercoespín & 7 & 2.627 & Nocturnal & $20: 00-5: 00$ \\
\hline & Sciurus aureogaster & Squirrel or Ardilla gris & 53 & 19.894 & Diurnal & $6: 40-18: 40$ \\
\hline \multirow[t]{4}{*}{ Carnívora } & Leopardus wiedii & Margay or Tigrillo & 6 & 2.252 & Nocturnal & 20:10-4:44 \\
\hline & Bassariscus sumichrasti & Ringtail or Sietillo or huiloncha & 2 & 0.750 & Nocturnal & 21:46-1:00 \\
\hline & Nasua narica & Tejón o Coatí & 8 & 3.003 & Diurnal & $08: 50-21: 50$ \\
\hline & Potos flavus & Kinkajou or Martucha & 25 & 9.384 & Nocturnal & $20: 30-4: 50$ \\
\hline
\end{tabular}

\section{DISCUSSION}

We recorded 12 of the 14 arboreal mammal species that have been reported for this region (González-Christen and Delfin-Alfonso 2016). Four of these species are listed in an extinction-risk category as the NOM-059-SEMARNAT-2010 (Diario Oficial de la Federación 2010, vr. 2019): the tropical cacomixtle or ringtail cat (Bassariscus sumichrasti) and the kinkajou (Potos flavus) are listed as under special protection; the Mexican tree porcupine (Coendou mexicanus), as threatened; and the margay (Leopardus wiedii), as endangered. Species not recorded in our study were the raccoon (Procyon lotor) and the tayra (Eira barbara). Gallina and González-Romero (2018) evaluated the diversity of terrestrial mammals in the RESG and recorded only nine species, including P. lotor, but did not record E. barbara either.

The Mexican gray squirrel (S. aureogaster) was active during the daylight period, a result consistent with that reported by Ramos-Lara and López-González (2017) for a pine-oak forest in the Sierra Gorda Biosphere Reserve (RBSG). A similar activity pattern was recorded for the gray squirrel in our study and the one by Ramos-Lara and LópezGonzález (2017), although a peak was recorded around 09:00 $\mathrm{h}$ in the RBSG, continuous activity was observed throughout the day, with no evident peak, in the RESG. This difference might be because $S$. aureogaster coexists with $S$. oculatus in the RBDG, which might lead to niche segregation. By contrast, no other squirrel that might compete for resources with S. aureogaster occurs in the RESG.

The observed activity pattern of $P$. flavus (see Figure 2) is consistent with the one documented in French Guyana (Julien-Laferriere 1993), although the activity peaks also differed. Our results show a unimodal activity pattern in the RESG, whereas it is bimodal in French Guyana (Julien-Laferriere 1993). This difference in activity peaks may be due to two reasons: 1) difference in sampling techniques, as Julien-

Laferriere used telemetry to monitor three individuals for 12 days, which allowed him to track their activity 24 hours a day, and 2) difference in the ecological characteristics of the habitat (e.g., climate, the structure of the tropical forest, food availability, presence of predators, among others) that might influence the activity patterns of $P$. flavus.

Our results show that the anteater (T. mexicana) had a nocturnal activity pattern (21:50-05:02 h); this is entirely different from what has been reported by other studies in tropical and subtropical ecosystems. For example, Brown

Sciurus aureogaster

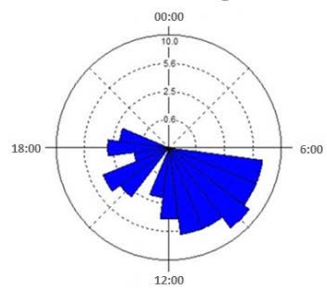

Potosflavus

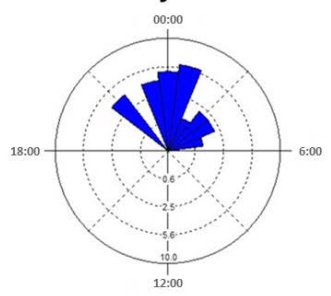

Tamandua mexicana

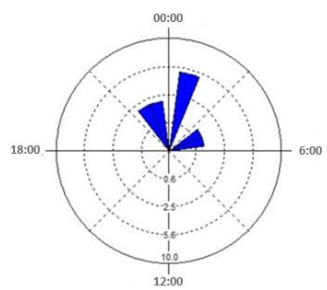

Figure 2. Daily activity patterns of canopy mammals. Blue bars denote the number of records on each hour of the day.

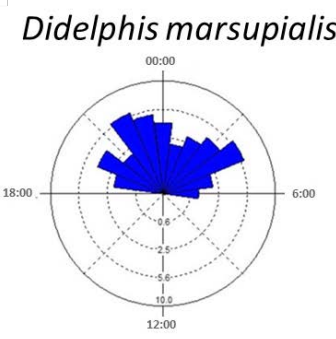

Tylomys nudicaudus

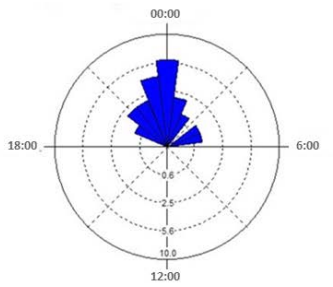


(2011) concluded that the activity pattern of this species in Barro Colorado Island, Panama, can be considered quasi cathemeral with a tendency to diurnal (7:00 - 22:00 h) and a peak around 15:00 $\mathrm{h}$. This species has been described as having highly variable habits, as they can be active during the daytime, the nighttime, or both (Montgomery 1985 a, b). The fact that the anteater displays a nocturnal activity pattern in some sites (as in this case) and diurnal in others evidences its ability to adapt to different or unfavorable situations (Montgomery 1985a, b; Brown 2011). One factor that might influence the observed activity pattern is the evasion of predators such as felines, raptors, or snakes (Izor 1985; Aranda 1994), or even poachers who often enter illegally the RESG with dogs (B. Vega Hernandez pers. comm.).

One factor that often limits the study of arboreal mammals is the low register success; a three-dimensional space such as the forest canopy makes detection difficult, as mammals can move along any of the three dimensions of the canopy. This is in clear contrast with ground-level studies in which only two dimensions are relevant, showing capturesuccess rates usually over $15 \%$ (Tobler et al. 2008; Lira-Torres and Briones-Salas 2012). Gallina and González-Romero (2018) attained a $14.5 \%$ capture success in the RESG.

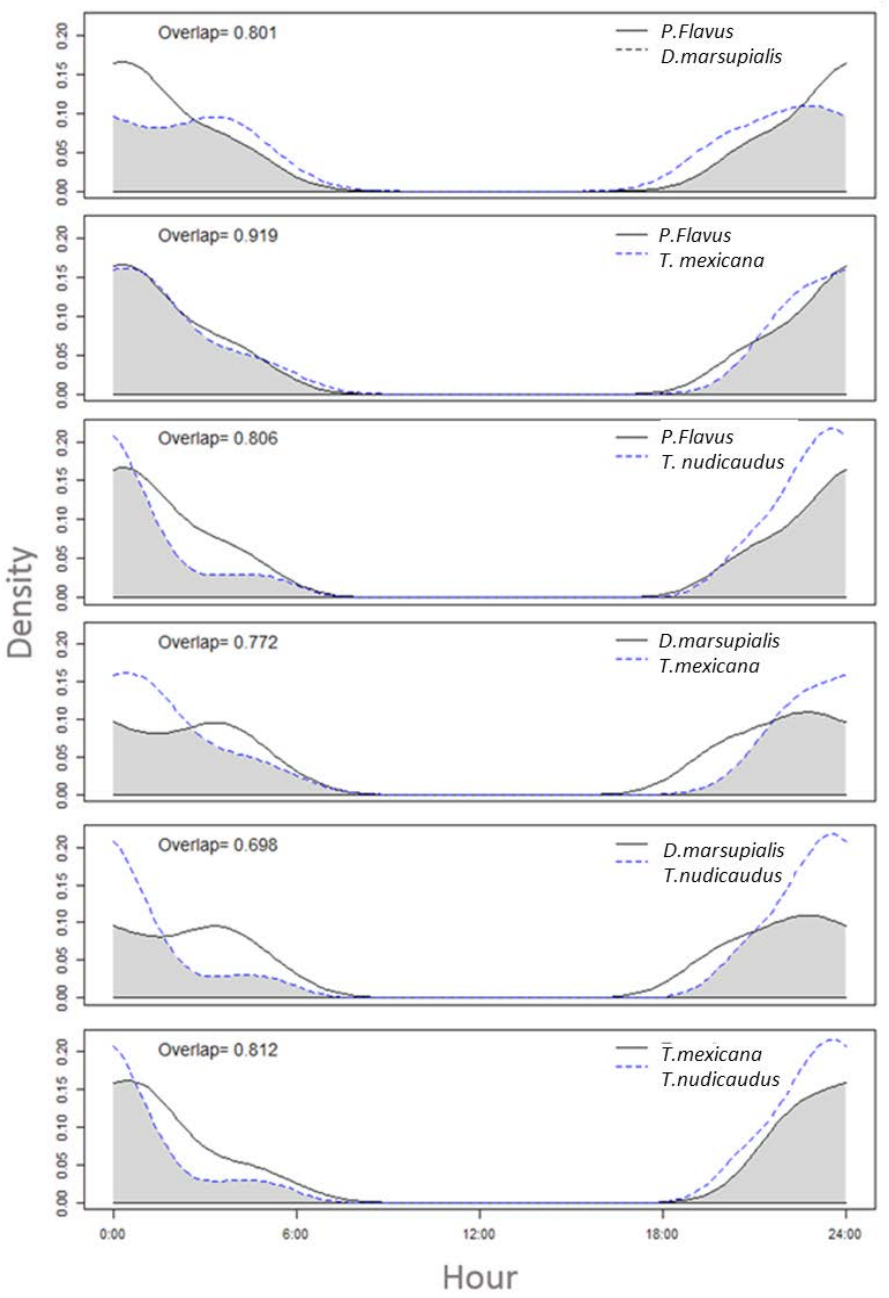

Figure 3. Overlapping between activity patterns of nocturnal species. The overlapping coefficient values range between 0 and 1 . The gray area represents the overlap between the species.
Our study is a first effort to document the species richness and activity patterns of mammals in the canopy of a tropical forest in Mexico. We recognize the importance of observing and describing in detail the activity patterns of mammals inhabiting tropical and subtropical ecosystems, although we were somewhat limited in the number of records obtained for some species. In this regard, we suggest carrying out longer-term studies to better understand how assemblages of arboreal mammals are distributed in space and time, allowing species coexistence.

\section{Acknowledgments}

We appreciate the support received from INECOL's strategic project 2003530908 "Refaunacion de áreas protegidas en el Estado de Veracruz" and PRODEP project 40857 DSA/103.5/14/10595/PTC-749 to acquire field equipment and gear. We thank CONACYT for the M.Sc. scholarship awarded to A. Astiazarán. We thank the staff of the R. E. Sta. Gertrude: the Vega Hernández family for granting access to the reserve; the Zárate family for their invaluable assistance during field trips; and M. Avendaño and F. Ocampo for their assistance with field sampling. M. E. Sánchez-Salazar translated the manuscript into English.

\section{Literatura citada}

Aranda, M. 1994. Importancia de los pecaries (Tayassu spp.) en la alimentación del jaguar (Panthera onca). Acta Zoológica Mexicana 62:11-22.

Bowler, M., M. Tobler, B. Endress, M. Gilmore, and M. Anderson. 2016. Estimating mammalian species richness and occupancy in tropical forest canopies with arboreal camera traps. Remote Sensing in Ecology and Conservation 1-12.

Brown, D. D. 2011. Activity patterns and space use of northern tamandua anteaters (Tamandua mexicana) on Barro Colorado Island, Panamá. Doctoral dissertation, University of California, Davis. Available from ProQuest Dissertations and Theses Global (Accession No. 908606114).

Charles-DominiQue, P. 1975. Nocturnality and diurnality an ecological interpretation of these two modes of life by an analysis of the higher vertebrate fauna in tropical forest ecosystem. Pp. 69-90 in Phylogeny of the Primates (Luckett, P. and F. Szalay, eds). Plenum Press. Wartenstein, Austria.

Chen M., M. Tewes, K. Pei1, and L. Grassman. 2009. Activity patterns and habitat use of sympatric small carnivores in southern Taiwan. Mammalia 73:20-26.

Comisión Nacional Del Agua (Conagua). 2016. Normales Climatológicas. Recuperado de http://smn.cna.gob.mx/es/ climatologia/informacion-climatologica.

DeCoursey P. 1990. Circadian photoentrainment in nocturnal mammals: ecological overtones. Biological Behavior 15:213-238.

Diario Oficial De La Federación. 2010. Norma Oficial Mexicana NOM-O59-SEMARNAT-2010, que determina las especies de flora and fauna silvestres terrestres y acuáticas, endémicas, amenazadas, en peligro de extinción and sujetas a protección especial. Órgano del Gobierno Constitucional de los Estados, Gobierno Federal, México.

Emmons, L., AND F. Feer. 1997. Neotropical rainforest mammals: A field guide, second edition. University of Chicago Press. 
Chicago, U.S.A.

Fernández-Duque, E. 2003. Influences of moonlight, ambient temperature, and food availability on the diurnal and nocturnal activity of owl monkeys (Aotus azarai). Behavioral Ecology and Sociobiology 54:431-440.

Gallina, S., And A. González-Romero. 2018. The conservation of medium-sized mammals in two private ecological reserves of Veracruz, Mexico. Revista Mexicana de Biodiversidad 89:1245-1254.

Gliwicz, J., AND M. Dabrowski. 2007. Ecological factors affecting the diel activity of voles in a multi-species community. Annales Zoologici Fennici 45:242-247.

Godínez-Ibarra, O., and L. López-Mata. 2002. Estructura, composición, riqueza y diversidad de árboles en tres muestras de selva mediana subperennifolia. Anales del Instituto de Biología 73:283-314.

Gómez, H., R. Wallace, G. Ayala, and R. Tejada. 2005. Dry season activity periods of some Amazonian mammals. Studies on Neotropical Fauna and Environment 40:91-95.

González-Christen, A., And C. A. Delfín-Alfonso. 2016. Los mamíferos terrestres de Veracruz, México y su protección. Pp. 499-534 in Riqueza y Conservación de los Mamíferos en México a Nivel Estatal (Briones-Salas, M., Y. HortelanoMoncada, G. Magaña-Cota, G. Sánchez-Rojas, and J. Sosa-Escalante eds.). Instituto de Biología, Universidad Nacional Autónoma de México, Asociación Mexicana de Mastozoología A. C. y Universidad de Guanajuato. Ciudad de México, México.

Halle, S., And N. Stenseth. 2000. Activity Patterns in Small Mammals: An Ecological Approach. Heildelberg, Springer Verlag Berlin.

IzoR, R. J. 1985. Sloths and other mammalian prey of the harpy eagle. Pp. 343-346 in the evolution and ecology of armadillos, sloths, and vermilinguas (Montgomery, G. G. ed). Smithsonian Institution Press. Washington, U.S.A.

Jiménez, C., F. Quintana, H. Pacheco, V. Melton, D. Torrealva, AND G. TelLo. 2010. Camera trap survey of medium and large mammals in a montane rainforest of northern Peru. Revista Peruana de Biología 17:191-196.

Julien-LaferRIere, D. 1993. Radio-tracking observations on ranging y foraging patterns by kinkajous (Potos flavus) in French Guiana. Journal of Tropical Ecology 9:19-32.

Kachamakova, M., AND D. Zlatanova. 2014. Behaviour of eurasian lynx, Lynx lynx (L.), in captivity during the breeding season. Acta Zoologica Bulgarica 66:365-371.

Kovach, W. L. 2011. Oriana: circular statistics for windows. Pentraeth: Kovach Computing Services, Anglesey, Wales.

LiRA-Torres, I., AND M. Briones-Salas. 2012. Abundancia Relativa Y Patrones De Actividad De Los Mamíferos De Los Chimalapas, Oaxaca, México. Acta Zoológica Mexicana 28:566-585.

Lynam, A., K. Jenks, N. Tantipisanuh, W. Chutipong, D. Ngoprasert, G. Gale, R. Steinmetz, R. Sukmasuang, N. Bhumpakphan, L. Grassman, P. Cutter, S. Kitamura, D. Reed, M. Baker, W. Mcshea, N. Songsasen, and P. Leimgruber. 2013. Terrestrial activity patterns of wild cats from camera-trapping. The Raffles Bulletin of Zoology 61:407-415.

Mandujano, S. 2019. Analysis and trends of photo-trapping in Mexico: text mining in R. Therya 10:25-32.

Méndez-Carvajal, P., M. Peñafiel, A. Zapata, and G. Berguido. 2015. The panamanian climbing rat, mammalia, rodentia, cricetidae, Tylomys panamensis (Gray, 1873): new report in Darien. Tecnociencia 17:47-56.

Montgomery, G. G. 1985a. Impact of vermilinguas (Cyclopes, Tamandua: Xenarthra $=$ Edentata) on arboreal ant populations. Pp. 351-363 in The Evolution and Ecology of Armadillos, Sloths, and Vermilinguas (Montgomery G.G ed.). Smithsonian Institution Press. Washington, U.S.A.

Montgomery, G. G. 1985b. Movements, foraging and food habits of the four extant species of Neotropical vermilinguas (Mammalia: Myrmecophagidae). Pp. 365-377 in The Evolution and Ecology of Armadillos, Sloths, and Vermilinguas (Montgomery G. G ed.). Smithsonian Institution Press Washington, U.S.A.

O'Brien, T. G., AND M. F. Kinnaird. 2011. Estimation of species richness of large vertebrates using camera traps: an example from an Indonesian rainforest. Pp. 233-252 in Camera Traps in Animal Ecology. Springer, Tokyo.

Oliveira-Santos, L., M. Tortato, and M. Graipel. 2008. Activity pattern of Atlantic Forest small arboreal mammals as revealed by camera traps. Journal of Tropical Ecology 24:563-567.

Pearson, O. 1959. A traffic survey of Microtus-Reithrodontomys runways. Journal of Mammalogy 40:169-180

Pearson, 0. 1960. Habits of Microtus californicus revealed by automatic photo records. Ecological Monographs 30:231-249 R Core Team. 2014. R: A language and environment for statistical computing. R Foundation for Statistical Computing, Vienna, Austria. URL http://www.R-project.org/.

Ramos-Lara, N., and C. A. López-González. 2017. Niche segregation between Sciurus aureogaster and S. oculatus in a disturbed forest in central Mexico. Journal of Mammalogy 98:1780-1790.

REID, F. A. 1997. A field guide to the mammals of Central America and Southeast Mexico. Oxford University Press. New York, New York, U.S.A.

Reid, F. A. 2009. A Field Guideto the Mammals of Central America \& Southeast Mexico. Oxford University Press, New York, U.S.A.

RIDOUt, M. S., AND M. LINKIE. 2009. Estimating overlap of daily activity patterns from camera trap data. Journal of Agricultural, Biological, and Environmental Statistics 14:322-337.

RowCLIFFE, J., AND C. CARBONE. 2008. Surveys using camera-traps: are we looking to a brighter future? Animal Conservation 11:185-186.

Sanderson, J. G., and M. Trolle. 2005. Monitoring elusive mammals: unattended cameras reveal secrets of some of the world's wildest places. American Scientist 93:148-155.

Secretaría de Agricultura Recursos Hidráulicos (SARH). 1982. Decreto por el que se establece la Zona Protección Forestal y Fáunica en la Región conocida como Santa Gertrudis, que se localiza dentro de una superficie de 925-00-00 Has. De propiedad particular en el Municipio de Vega de Alatorre, Ver., DOF:16/08/1982. Secretario de Agricultura y Recursos Hidráulicos. Estados Unidos Mexicanos. Presidencia de la República.

SCHIPPER, J. 2007. Camera-trap avoidance by Kinkajous Potos flavus Rethinking the "non invasive" paradigm. Small Carnivore Conservation 36:38-41.

Szymanski, J. 1920. Aktivitat und Ruhe bei Tieren und Menschen. Zeitung Allgemeine Physiologie 18:105-162. 
Tobler, M., S. Carrillo-Percastegui, R. Leite, R. Mares, and G. Powell. 2008. An evaluation of camera traps for inventorying large-and medium-sized rainforest mammals. Animal Conservation 11:169-178.

Van Schaik, C., AND M. Griffiths. 1996. Activity Periods of Indonesian Rain Forest Mammals. Biotropica 28:105-112.

Wauters, L. A. 2000. Squirrels medium-sized granivores in woodland habitats. Pp. 67-90 in Activity Patterns in Small Mammals an Ecological Approach (Halle, S. and N. C. Stenseth, eds.). Springer- Verlag. Heildelberg, Berlin.

Whitworth, A., L. Dominie, R. Pillco, R. Macleod, and C. Beirne. 2016. Out on a limb: arboreal camera traps as an emerging methodology for inventorying elusive rainforest mammals. Tropical Conservation Science 9:675-698.

Associated editor: Rafael Reyna

Submitted: March 22, 2019; Reviewed: May 6, 2019;

Accepted: March 31, 2020 Published on line: May 262020. 
232 THERYA Vol. 11 (2): 225-231 